http://dx.doi.org/10.4314/jae.v17i1.3

\title{
Approaches to Economic Empowerment of Rural Women for Climate Change Mitigation and Adaptation: Implications for Policy
}

\author{
E.N. Ajani ${ }^{\star}$, E.A. Onwubuya ${ }^{\star *}$ and R.N. Mgbenka $a^{\star \star *}$ \\ lyneajani@gmail.com ${ }^{\star}$, lizzybuya@yahoo.com ${ }^{\star \star}$ and amakamg@yahoo.com ${ }^{\star \star \star}$ \\ Department of Agricultural Extension, Faculty of Agriculture, University of Nigeria, \\ Nsukka
}

\begin{abstract}
There are several ways of promoting women's economic participation while also counteracting climate change. One approach in the field of climate mitigation is the promotion of renewable energies that help avoid greenhouse gas emissions. The potential of rural women as agents of change for climate mitigation and adaptation remains untapped: Their extensive theoretical and practical knowledge of the environment and resource conservation is not given due consideration. In terms of economic participation, they are not paid for the environmental services that they already provide (example, reforestation). The potential contribution of rural women to climate mitigation by being part of the economic cycle is not sufficiently exploited. The economic empowerment of women through climate mitigation and adaptation fosters economic growth and socioeconomic development, reduces poverty, keeps environmental problems in check, and increases the potential for adaptation, which is to the benefit of both women and men. Enhancing the economic empowerment of women is a catalyst for development, which helps boost a country's economic growth, promotes the socioeconomic development not only of women, but of the entire population, and helps reduce poverty. It is observed that less attention is paid to the potential that lies in the combination of climate mitigation/ adaptation and the economic empowerment of rural women. Yet mitigation or adaptation activities offer opportunities to advance the economic empowerment of women. In particular, this applies to work that is already being undertaken by women or activities in which women could assume a leading role. In developing countries, for instance, women frequently play a major role in the reforestation and afforestation of cleared land and in forest conservation, yet they have hardly ever benefited from these environmental services. The paper addresses the economic empowerment of rural women through climate change mitigation and adaptation. The study recommends that measures to promote the economic participation of women can be integrated into climate mitigation and adaptation initiatives. In order for rural women to play an economic role, an institutional, legal and political framework is required that enables and/or makes it easier for rural women to hold their own in the market. Concrete, promising project measures at the local level should therefore be combined with advisory services at the political level related to climate change and the economic empowerment of women, with a view to initiating structural reform.
\end{abstract}

Key words: Empowerment, rural women, climate, mitigation and adaptation. 


\section{Introduction}

Climate change effects vary among regions, generations, age, classes, income groups, occupations and gender. There are, however, several ways of promoting women's economic participation while also counteracting climate change. One approach in the field of climate mitigation is the promotion of renewable energies that help avoid greenhouse gas emissions (Denton, 2002). It is increasingly recognised that empowering women, children and other marginalised groups is beneficial not only as a policy in itself, but also as a means of strengthening the effectiveness of climate change measures (United Nations Development Programme (UNDP), 2009; Deutsche Gesellschaft für Technische Zusammenarbeit GmbH (GTZ), 2010). Women in rural areas in developing countries, for example, are the principle producers of basic foods and have thus taken action to conserve soil and water. Various examples in different countries are provided where women's knowledge and activism have helped to control erosion, prevent flood damage, and improve access to water. Women should be included in decision-making in order to allow their knowledge to benefit entire communities. Knowledge of how women are affected by climate change is essential for their effective involvement in the climate change response and for harnessing their capacity for appropriate mitigative action.

Worldwide, women have less access than men to resources that would enhance their capacity to adapt to climate change, including land, credit, agricultural inputs, decision making bodies, technology and training services (Women's Environment \& Development Organization (WEDO), 2007). For the vast majority of women working in the informal sector and in small enterprises, lacking capital and access to credit and information, recovering from the devastating effects of environmental disasters is nearly impossible (Organization for Economic Cooperation and Development (OECD), 2008).

In many countries, droughts, floods and deforestation increases work burdens for many women leaving them less time to earn income, get an education, or provide care to their families. Girls regularly drop out of school to help their mothers gather fuel wood and water. Extreme weather conditions and natural disasters also increase their exposure to infectious diseases, such as cholera and HIV/AIDS (Klasen and Lamanna, 2008). Continued global warming will extend the areas affected by malaria. Conflicts driven by climate change and disasters can increase women's vulnerability to violence (UNDP, 2007).

Women also function as change agents in community natural resource management, innovation, farming and care giving and hold the key to adaptation to climate change. Responsibilities in households, communities and as stewards of natural resources position them well to developing strategies for adapting to changing environmental realities.

Experience has shown that communities fare better during natural disaster when women play a leadership role in early warning systems and reconstruction. Women tend to share information related to community well being, choose less polluting energy sources, and adapt more easily to environmental changes when their family's survival is at stake (WEDO, 2007). 
According to the Food and Agricultural Organization(FAO) (2007), women and men are adapting their agricultural practices to naturally-varying climate conditions based on their specific needs, knowledge and access to resources. An FAO study found that when gender differentiated knowledge is properly understood and addressed, interventions to strengthen livelihoods and food security are more effective and efficient (FAO, 2007).

In rural areas of many developing countries there is a lack of energy services. This mainly affects women in their daily work in the home, since they are usually responsible for providing energy for the household, such as heating and cooking. Without access to convenient, affordable fuels, women may spend up to three hours a day gathering fire wood and other energy sources. Energy on the other hand may also be a starting point for income-generating activities (Mitchell,Tanner and Lussier (2007). Probably the best-known example that combines renewable energy, jobs and skills training is the Grameen Shakti (GS) microloans initiative in Bangladesh. GS has helped to install more than 100,000 solar home systems in rural communities, creating employment opportunities while also empowering women and local youth (Intergovernmental Panel on Climate Change, (IPCC), 2007).

Climate change produces new and different weather patterns and extreme weather events; and research findings support the view that women's economic insecurity increases more than men's in the aftermath of natural disasters (Enarson, 2000). Women also recover more slowly than men from economic losses due to damage to property and the loss of livelihood (Athen, 2009).

Food, water, health and energy are particularly affected by climate change. These areas happen to be the bases of women's livelihoods and fall within the purview of women's socio-economic responsibilities (International Union for Conservation of Nature (IUCN), 2007). For instance, women are often in charge of growing and preparing food, gathering firewood for fuel, collecting water and caring for the ill in their families and communities, all of which tasks become more gruelling and time consuming with the increased occurrence of floods and droughts associated with climate change.

Moreover, women's lack of property rights and control over natural resources aggravated by their limited access to information, education, credit and technologies -translate to fewer means to deal with climate change. Adaptation measures, related to anti-desertification, are often labour-intensive and women often face increasing expectations to contribute unpaid household and community labour to soil and water conservation efforts. Women often rely on a range of crop varieties (agrobiodiversity) to accommodate climatic variability, but permanent temperature change will reduce agro-biodiversity and traditional medicine options (Aguilar, 2004).

Additionally, women are consistently underrepresented in policy and decisionmaking processes around climate change at the local, national and global levels (Brody, Demetriades and Espen,2008; IUCN, 2007). This is a matter of concern not only because women comprise one of the most vulnerable groups of people, but also because women play a pivotal role in mitigating and adapting to climate change. As heads of households, active community leaders and members, and stewards of natural resources, women can and have offered different perspectives and resources 


\section{Journal of Agricultural Extension}

Vol. 17 (1) June, 2013

ISSN 1119-944X

in responding to climate change challenges. Case studies suggest that women have a better understanding of the causes and consequences of climate change and have the knowledge and skills to mitigate and adapt to changing weather conditions (O'Connor, Bord and Fisher, 1998; Röhr, 2007). For all of these reasons, financing policies for climate change mitigation and adaptation must explicitly consider as well as respond to the different experiences and needs of women, especially those women who are on the socio-economic margins of society.

The protection of livelihoods and sources of sustenance among rural women are paramount, entailing adaptation measures that build in climate resilience in agriculture and fishery, ensure people's access to potable water and other necessities, and provide social insurance and protection, among others. Adapting to and mitigating climate change will entail a transition to new patterns of production, consumption and employment. Huge opportunities exist to create jobs through energy and industrialization policies that reduce the environmental footprint. These jobs can provide decent work and incomes that will contribute to sustainable economic growth and help lift people out of poverty. Women, with their unique knowledge and capabilities of natural resource management and use of energy sources are strong change agents and key contributors to climate change mitigation and adaptation programmes at local, regional and international levels (International Labour Organization (ILO), 2008).

The economic empowerment of women through climate mitigation and adaptation fosters economic growth and socioeconomic development, reduces poverty, keeps environmental problems in check, and increases the potential for adaptation, which is to the benefit of both women and men (Bäthge, 2010).

The paper is designed to review approaches to economic empowerment of rural women through climate change adaptation and mitigation measures. The paper relied mostly on current literature and observations about climate change.

\section{Adaptation measures of climate change among rural women}

Areas in which women are traditionally engaged and which are closely tied to the availability of natural resources (e.g., food security, domestic energy and water) will be hit particularly by the consequences of climate change (WEDO, 2008) and require greater adaptation. With regard to climate adaptation, it should be noted that women often do not have much of a say in decisions taken by the family or the community and are therefore unable to diversify cultivation, for example (Rodenberg, 2009). Furthermore, it is usually women who are responsible for collecting water and fuel (e.g., firewood) for the household. The scarcity of these resources induced by climate change increases a woman's workload and time poverty, burdened as she already is by the many roles she has to play. She is consequently left with no time for income-generating activities, education, training or participation in community decision making processes. In overall terms, climate change intensifies the existing economic and social gender disparities (Rodenberg, 2009).

Apart from the differential vulnerability, the sexes also play different roles in dealing with climate change. It is generally recognised that women are major actors in mitigation and adaptation measures (IUCN, 2007; Rodenberg, 2009; UNDP, 2009; 


\section{Journal of Agricultural Extension}

Vol. 17 (1) June, 2013

ISSN 1119-944X

United Nations Population Fund (UNFPA)/WEDO, 2009) and their role in adaptation measures in developing countries is often highlighted. Women play a particularly significant role in ensuring a family's food security. They shoulder the responsibility for this activity, have extensive knowledge about their natural surroundings, and are at the forefront in the conservation and selection of seeds of different crops (IUCN/ UNDP/Global Gender and Climate Change Alliance (GGCA), 2009). In many areas women are already adapting to the fallout of climate change and are fully aware of where their own needs and those of their families lie (BRIDGE, 2008).

According to WEDO (2007) greater decision-making powers for women at the family and community level with regard to agricultural cultivation and the farming of new and more resistant crops could increase agricultural production, leading to greater food security, the production and marketing of surpluses, and ultimately to a source of income.

In order to effect comprehensive adaptation to changing climatic conditions, a number of measures in vastly different sectors and at different levels are needed (Athen, 2009). In concrete terms, the adaptation measures required with reference to climate change, gender, and the advancement of women's economic empowerment should specifically enable women to secure or expand their livelihood options. In the context of agricultural production, in which most of the women work to ensure food security for the family (IUCN/UNDP/GGCA, 2009), this refers primarily to the use of cultivation and irrigation methods that allow for crop security even in the case of natural resource depletion or unforeseen weather events. In irrigation, it is important to adapt type, time, and use (IUCN/UNDP/GGCA, 2009). Ideally, one can switch from traditional irrigation methods to efficient and modern irrigation systems. As regards cultivation methods, it is advisable to select crops that can flourish despite floods or heat waves or those with a short growth cycle which can, for example, be harvested before the flooding season or can be planted during the (short) rainy season. Moreover, it would be possible to grow different crops on one and the same field in order to optimise the use of soil and irrigation and perhaps to counter the onset of erosion. Locally produced organic fertiliser could also be used that would not only fertilise the soil, but would also prevent disease or ensure crop survival in times of drought. These adaptation measures could actually increase production and with the existing resources, the highest possible yields could be attained.

However, complementary training and agricultural extension services are required to teach women about the economical use of scarce resources, processing and marketing methods for agricultural products. The latter includes converting raw materials into derivates (value addition)that usually fetch higher prices and reduce dependence on raw material prices (Bathge, 2010).

\section{Mitigation measures of climate change among rural women}

The role of women in mitigation measures should not be under-estimated. Developing countries have the potential to reduce or store greenhouse gases, particularly in areas in which women are already active. Thus providing energy for the household is usually a woman's job and she often resorts to the energyinefficient open burning of biomass, e.g., firewood. The use of efficient energy systems at the household level (e.g., special cooking stoves and ovens) could 
reduce emissions and harness the potential of women as actors for mitigation measures (IUCN/UNDP/GGCA, 2009). Women worldwide are also involved in natural resource and forest conservation. The forests supply women with vital products and are used not just to gather firewood, but also to obtain other raw materials, food or medicinal plants to provide for their families and to boost their income (IUCN/UNDP/GGCA, 2009).

The conservation and care of forests coupled with reforestation and afforestation for which women are responsible helps avoid the emissions caused by deforestation and leads to greater sequestration of greenhouse gases from the atmosphere. Women therefore contribute directly to climate mitigation. Given their significant role in mitigation and adaptation efforts, it is imperative that women be involved in the relevant measures of climate change mitigation (Aguilar, 2004).

\section{Ways of strengthening economic empowerment of rural women for climate change adaptation and mitigation.}

Access to education, training and upgrading: In the context of climate, measures designed for training and continuing education could be particularly significant in the following areas:

- Awareness of the causes and consequences of climate change in order to sensitise rural women on the dangers of climate change and to the possible requirements/mechanisms of adaptation

- Awareness of existing mitigation and adaptation programmes in which rural women can be involved and from which they can benefit.

- Training programmes on adaptation measures with a special focus on the needs of rural women (example, alternative cultivation methods and more resistant crops in agriculture, more efficient domestic and agricultural use of available water resources, alternative sources of domestic energy).

- Training programmes on the use of (new) technologies (example, means of agricultural production, energy-efficient cooking stoves and ovens, renewable energy systems, information and communication technologies).

- Awareness of existing rights and laying claim to these rights in different spheres of life (example, land ownership or land use rights, ownership rights for means of production).

Access to and control over productive resources (access to land and ownership rights) This is important because it will help them to:

- own land and be able to use it according to one's own needs and wishes in order to be active in climate mitigation and adaptation.

- procure, own and be able to use the means of production, particularly new technologies, and the related technical know-how.

- obtain, own, and be able to deploy financial capital for one's own undertakings in order to have investments available for the adoption or development of climaterelated work.

\section{Access to services}

- to have access to (medical) care and child-care services in order to ease the burden on women, reduce time poverty, and gain more time for income-generating activities.

- to have access to the (agricultural) extension services required, for example, to expand agricultural production or nature and resource conservation work. 
- to be able to formalise one's own enterprise, which involves neither a great deal of time nor money.

Access to markets (land, labour, financial and product markets) - In this context implies:

- to be able to acquire (additional) land or sell it.

- to be able to use one's own labour in the formal and informal labour markets, to have access to loans and funds and, in the context of climate, access to international climate finance mechanisms (e.g., climate funds or CDM).

- to be able to access product markets to sell one's own products and so have access to the information required about market prices and trading options (WEDO, 2008).

\section{Economic activities of rural women that reduces climate change effects \\ a. Greenhouse gas reduction: natural resource conservation}

climate change and its consequences may pose challenges, there are also opportunities to be found in adaptation and mitigation. In several developing countries, the people (women) are already engaged in traditional work that does not cause greenhouse gas emissions or captures emissions that have been released. Several commitments to enhance the economic empowerment of women have also been made by donors and partners at international, transnational and national levels (Ramani, 2002).

An example of natural conservation resource project is Green Belt Movement. The Green Belt Movement (GBM) is a Kenyan women's NGO that began to plant trees at the grassroots level in 1977 to tackle the problems of deforestation, soil erosion and water scarcity. The programme has since evolved into an instrument that facilitates the empowerment of women. It pursues a holistic approach, as trees (including fruit and other commercial trees) are planted by voluntary networks of women and their families. The participants are also trained in sustainable agriculture with the aim of diversifying their livelihoods and earning an income. They undergo comprehensive capacity building in food production, processing and marketing, apiculture, and the planting and care of trees, activities that aim to empower women to generate an income of their own (Kabeer, 2001).

The programme makes an overall contribution to climate mitigation, as emissions are hindered and absorbed because existing trees are cared for and new ones planted. A contribution is also made to climate adaptation, as the communities learn about the sustainable use of scarce resources and about sustainable agricultural techniques. And finally, the Green Belt initiative also empowers women economically, as they now have alternative sources of income created by the planting and caring of trees (GBM, 2009, World Bank, 2006).

The Kinawataka Women's Development Initiatives in Uganda is an example of green recycling where the non-profit organization located in the suburbs found a way of turning used plastic straws, bags and other non-biodegradable waste items that were clogging drainage systems and contaminating the soil into a profitable enterprise. The women turn the waste items into useful products such as handbags, earrings, bags, belts and mats. Recent training in record keeping, organizing exhibitions and advertising provided by the ILO's Women's Entrepreneurship Development and 


\section{Journal of Agricultural Extension}

Vol. 17 (1) June, 2013

ISSN 1119-944X

Gender Equality Programme (WEDGE) helped improve the business' bottom line and provide worldwide recognition of their fashionable products (OECD, 2008).

As part of the reforestation and afforestation efforts, women can also plant trees that not only sequester emissions, but also produce a crop (agroforestry), which may provide them with a source of income (USAID, 2005). Besides adapting production methods, it is also important to conserve soil and water sources as the basis of agricultural production. Here, too, women across the world are involved as central players and therefore could make a significant contribution towards meeting adaptation requirements(IUCN/UNDP/GGCA, 2009). Soil degradation and the unused water runoff could, for instance, be reduced by planting the area or by constructing infiltration ditches (WEDO/ABANTU for Development/ ActionAid/ENDA, 2008). According to a case study from Senegal, women are keen to address the problem of erosion mainly because erosion reduces their agricultural productivity and makes it more difficult for them to access water (WEDO/ABANTU for Development/ActionAid/ENDA 2008). Both are fundamental requirements if production is to be increased and is to generate income. In addition to soil and water sources, ecological systems in the wider sense must be rehabilitated to conserve soil, water sources and habitat and therefore also to maintain the basis for life and livelihoods. Women are already engaged in work that addresses the rehabilitation of eco-systems encompassing not just traditional forests but, for instance, mangrove forests as well. They thus help combat desertification and the loss of biodiversity in coastal regions (WEDO/ABANTU for Development/ ActionAid/ENDA, 2008).

\section{b. Energy}

As is the case with the cultivation of agricultural products for the market, the energy sector is also largely viewed as a male sector in which women are assigned a minor role (Carlsson, 2007). However, in most developing countries, domestic energy, e.g., for cooking, heating or lighting is still obtained from the energy-inefficient and toxic burning of biomass, such as wood, charcoal or agricultural waste, which is traditionally women's work (Carlsson, 2007). Even when households are connected to an electricity network, the power available is usually used only for smaller electrical gadgets and for lighting; it is not used as a substitute for biomass, particularly not in rural areas (Carlsson, 2007). Women therefore continue to spend enormous amounts of time on procuring the biomass they require and they need larger amounts of fuel as they burn it inefficiently. Not only does this give them even less of an opportunity to pursue alternative, income-generating activities, but, as it is virtually impossible for them to meet this need sustainably, the practice exacerbates deforestation, land degradation and desertification (GTZ HERA, 2007). The use of energy-efficient stoves and ovens could help reduce unhealthy emissions and improve the situation described, not least because these stoves and ovens reduce the quantity of biomass required while cutting down on cooking time (GTZ HERA, 2009).

Besides energy-efficient ovens, it is particularly important for the rural population to be connected to the electrical grid, with electricity ideally generated by renewable energy. The production factor that is most readily available to women is the use of their own labour (UN, 2009). Hence the bulk of a woman's income-generating activities is labour-based, hence greater attention should be paid to the issue of 


\section{Journal of Agricultural Extension}

Vol. 17 (1) June, 2013

ISSN 1119-944X

energy supply as it is directly responsible for reducing the human workload involved in production (Ramani, 2002). In other words, power is required to run electricitybased means of production that would increase a woman's productivity while reducing her workload as well as mitigate climate change.

However, in climate mitigation and adaptation measures women must therefore be perceived as actors with specific needs. For women to play an economic role, an institutional, legal and political framework is required that enables and/or makes it easier for women to adapt to climate change and maintain economic empowerment. Additionally, pilot experiences in climate adaptation have shown that women, given their vast knowledge, are able to develop and disseminate innovative cultivation methods that are adapted to climate change (Carlsson, 2007).

For mitigating climate change, women propose more comprehensive approaches and tend to focus more on lifestyle and behavioral changes to reduce greenhouse gas emissions and are more skeptical about technology will solve the problem of global warming (OECD, 2008).

\section{Actions to promote climate change adaptation and mitigation among rural women}

- Tapping into the vast knowledge and natural resource management abilities of women when devising adaptation and mitigation policies and initiatives for climate change.

- Mainstreaming gender perspectives into international and national policies.

- Ensuring that women and men participate in decision- and policy-making processes.

- Promoting participatory approaches in local and community planning activities.

- Creating opportunities at the national and local level to educate and train women on climate change, stimulate capacity building and technology transfer and assign specific resources to secure women's equal participation in the benefits and opportunities of mitigation and adaptation measures.

- Gathering new sex-disaggregated data and gender analysis in key sectors such as agriculture, forestry, energy and water usage to further understand how climate change impacts on women's lives (ILO,1998).

\section{Conclusion and Recommendations}

The combination of climate change and the economic empowerment of women creates an opportunity for both fields to create mutual synergy on the path to poverty reduction and development. Any response to climate change should be mainstreamed into national, sectoral and local development strategies. Both adaptation and mitigation policies will need to include strategies for enhanced social protection, enterprise development and employment generation among rural women.

Identification and implementation of programmes to support education and training initiatives that will facilitate the development of the skills necessary for creation of employment among rural women who are vulnerable to climate change remains paramount. If women are to be empowered to take strategic decisions, it is advisable to supplement the measures at the target group level with long-term structural approaches. However, an integrated approach involving institutional and political measures are required to create the basic structural conditions necessary for 


\section{Journal of Agricultural Extension}

Vol. 17 (1) June, 2013

ISSN 1119-944X

sustainable economic empowerment of rural women for climate change adaptation and mitigation.

\section{References}

Aguilar, L. (2004). Fact Sheet on: Climate change and disaster mitigation. Costa Rica. IUCN.

Athen, P. (2009). Financing for Climate Change Mitigation and Adaptation in the Philippines: A Pro-poor and Gender-Sensitive Perspective. Reality Check, pp. 1-14.

Bäthge, S. (2010). Climate change and gender: economic empowerment of women through climate mitigation and adaptation? Working Paper, Deutsche Gesellschaft für Technische Zusammenarbeit (GTZ) GmbH Eschborn Germany, pp. 1-22.

BRIDGE (2008). Gender and climate change: mapping the linkages. As coping study on knowledge and gaps

http://www.bridge.ids.ac.uk/reports/Climate CChange DFID.pdf (20.01.2010)

Brody, A., J. Demetriades and E. Espen (2008), Gender and Climate Change: Mapping the Linkages, BRIDGE-Institute of Development Studies: Sussex, retrieved

from

http://www.bridge.ids.ac.uk/reports/Climate Change DFID draft.pdf.

Carlsson, G. (ed.) (2007), Where Energy is Women's Business. National and Regional Reports from Africa, Asia, Latin America and the Pacific http://www.energia.org/fileadmin/files/media/pubs/karlsson csdbook lores.pdf (09.08.2010)

Denton, F. (2002). Climate change vulnerability, impacts, and adaptation: Why does gender matter? Gender and Development, vol. 10 (2), pp. 10-20.

Enarson, E. (2000). Gender Issues in Natural Disasters: Talking Points and Research Needs in Focus Programme on Crisis Response and Reconstruction Workshop, ILO: Geneva.

Food and Agriculture Organisation (FAO) (2007). People-centred climate change adaptation: Integrating gender issues, Policy Brief, Rome.

Green Belt Movement (GBM) (2009). Responding to climate Change from the Grassroots: The Green Belt Movement Approach.<http://greenbeltmovement.org/downloads/2009_climate_change report_short_GBM.pdf> (09.02.2010)

GTZ Deutsche Gesellschaft für Technische Zusammenarbeit (GTZ) (2010). Climate Change and Gender: Economic Empowerment of Women through Climate Mitigation and Adaptation?, Working Paper, Governance and Democracy Division,

GTZ

Governance

Cluster 
http://www.climatehealthconnect.org/sites/climatehealthconnect.org/files/resour ces/17353 diskussionspapierenlayoutgc12941558.pdf

GTZ HERA (2007). Cooking Energy. Why it really matters if we are to halve poverty by 2015 <http://www.gtz.de/de/dokumente/encooking-energy-2007.pdf> (03.02.2010)

Intergovernmental Panel on Climate Change (IPCC) (2007). Climate Change 2007: Mitigation of Climate Change, IPCC: Bangkok.

International Labour Organization (ILO) (2008). Report of the Committee on Employment and Social Policy, Employment and labour market implications of climate change, Fourth Item on the Agenda, Governing Body, 303rdSession (Geneva), p. 2.

International Union for Conservation of Nature (2007). Gender Aspects of Climate Change, Briefing paper, retrieved from http://www.iucn.org/en/news/archive/2007/03/7_gender_climate_change.pdf.

International Union for Conservation of Nature (IUCN/UNDP/GGCA) (2009). Training Manual on Gender Climate Change http://data.iucn.org/dbtw-wpd/edocs/2009012.pdf (03.02.2010).

Kabeer, N. (2001). Resources, Agency, Achievements: Reflections on the Measurement of Women's Empowerment. In: B. Sevefjord, N. Kabeer, P. McFadden, S. Arnfred, E. Dominguez and S. Saadallah (eds.), Discussing Women's Empowerment: Theory and Practice, p. 17-57 Stockholm: Sida Studies No.3<http://www2.sida.se/shared/ssp/download.jsp?f=SidaStudies+No3.pdf\&a=2 $080(06.08 .2010)$

Klasen, S. And Lamanna, F. (2008). The Impact of Gender Inequality in Education and Employment on Economic Growth in Developing Countries: Updates and Extension <http://ideas.repec.org/p/got/iaidps/175.html> (29.10.2010)

Mitchell, T., T. Tanner and K. Lussier (2007). We Know What We Need: South Asian Women Speak Out on Climate Change Adaptation, Action Aid: London, retrieved from $\quad$ http://www.actionaid.org/assets/pdf/ActionAid\%20\%20IDS\%20 Report\%20_We\%20know\%20what\%20we\%20need.pdf.

O'Connor, R. E., Bord, R.J. and Fisher, A. (1998). The Curious Impact of Knowledge about Climate Change Risk Perceptions and Willingness to Sacrifice, Risk Decision and Policy, vol. 3, pp.145-155.

Organization for Economic Cooperation and Development (OECD) (2008). Gender and Sustainable Development, maximizing the economic, social and environmental role of women (Paris), pp. 73-74.

Ramani, S. (2002). Energy as an Instrument of Women's Economic Empowerment, 


\section{Journal of Agricultural Extension}

Vol. 17 (1) June, 2013

ISSN 1119-944X

\section{ENERGIA}

News

vol. 5

http://www.energia.org/resources/newsletter/pdf/EN042002ramani.pdf, pp. 810. (18.02.2010).

Rodenberg, B. (2009). Climate Change Adaptation from a Gender Perspective. German Development Institute Es sind die Machtverhältnisse, die Frauen für denKlimawandel verwundbarer machen', Böll THEMA, Heft 2/2009,p. 14<http://www.boell.de/downloads/publikationen/BoellThema_2.2009_abRea der7kommentierbar.pdf> (07.01.2010)

Röhr, U. (2007). Gender, Climate Change and Adaptation: Introduction to Gender Dimensions, retrieved from http://www.bothends.org/service/casestudy_genanet.pdf.

United Nations (UN) (2009). 2009 World Survey on the Role of Women in Development. Women's Control over Economic Resources and Access to Financial Resources, including Microfinance $<$ http://www.un.org/womenwatch/daw/public/WorldSurvey2009.pdf> $(21.01 .2010)$

United Nations Development Programme (UNDP) ( 2007). Human Development Report 2007/2008, Fighting Climate Change: Human solidarity in a divided world (New York), pp. 81-82.

United Nations Development Programme (UNDP) (2009). Resource Guide on Gender and Climate Change<http://content.undp.org/go/cmsservice/ download/asset/

United Nations Population Fund (UNFPA/WEDO) (2009). Climate Change Connections. Gender and Population http://www.wedo.org/category/act/climate-change-toolkit (16.10.2009)

USAID (2005). Trade Liberalization, Economic Growth and Gender $<$ http://forestle.org/goto.php?url=http\%3A\%2F\%2Fwww.usaid.gov\%2Four_wo rk\%2Fcrosscutting_programs\%2Fwid\%2Fpubs\%2FLiberalization_Gender_Tr ade_fact_sheet_2005.pdf> (19.02.2010)

World Bank (2006). Gender Equality as Smart Economics: A World Bank Group Gender Action Plan (Fiscal years 2007-10) <http://siteresources.worldbank.org/INTGENDER/Resources/GAPNov2.pdf> (26.01.2010).

Women's Environment \& Development Organization (WEDO) (2007). Changing the Climate: Why women's perspectives matter, New York, p. 3.

Women's Environment and Development Organization (WEDO/ABANTU) for Development/Action Aid/ENDA (2008). Gender, Climate Change and Human Security: Lessons from Bangladesh, Ghana and Senegal<http://www.wedo.org/wp-content/uploads/hsn-study-final-may-202008.pdf> (09.02.2010). 